\title{
Current Concepts of Percutaneous Balloon Kyphoplasty for the Treatment of Osteoporotic Vertebral Compression Fractures: Evidence-based Review
}

\author{
Ming-Kai Hsieh, Lih-Huei Chen, Wen-Jer Chen
}

\begin{abstract}
Vertebral compression fractures constitute a major health care problem, not only because of their high incidence but also due to both direct and indirect consequences on health-related quality of life and health care expenditures. The mainstay of management for symptomatic vertebral compression fractures is targeted medical therapy, including analgesics, bed rest, external fixation, and rehabilitation. However, anti-inflammatory drugs and certain types of analgesics can be poorly tolerated by elderly patients, and surgical fixation often fails due to the poor quality of osteoporotic bone. Balloon kyphoplasty and vertebroplasty are two minimally invasive percutaneous surgical approaches that have recently been developed for the management of symptomatic vertebral compression fractures. The purpose of this study was to perform a comprehensive review of the literature and conduct a meta-analysis to compare clinical

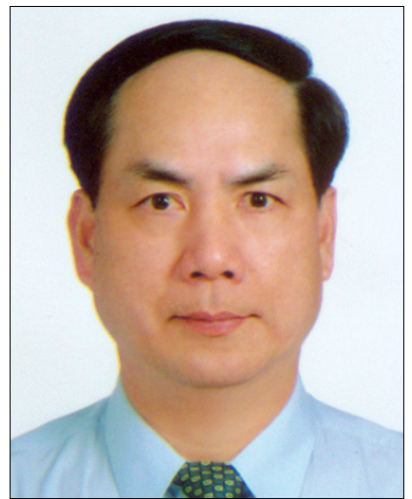

Dr. Lih-Huei Chen outcomes of pain relief and function, radiographic outcomes of the restoration of anterior vertebral height and kyphotic angles, and subsequent complications associated with these two techniques. (Biomed J 2013;36:154-161)
\end{abstract}

Key words: balloon kyphoplasty, osteoporosis, vertebral compression fracture, vertebroplasty

$\mathrm{V}$ ertebral compression fractures (VCFs) constitute a major health care problem, not only because of their high incidence but also due to both direct and indirect consequences of VCFs on health-related quality of life and health care expenditures. ${ }^{[1-3]}$ Approximately $26 \%$ of women over 50 years old and $40 \%$ of women over 80 years old are reported to have sustained a VCF ${ }^{[4,5]}$ However, only one-third to three-quarters of such patients then develop chronic back pain, ${ }^{[1]}$ which may be attributed to pseudarthrosis or to osteoporotic spinal deformities such as kyphosis or kyphoscoliosis. The degree of kyphosis correlates well with the patient's physical function, risk of further fractures, ${ }^{[6,7]}$ compression of the spinal cord, mental well-being, and pulmonary function, ${ }^{[8]}$ any of which may contribute to an increased mortality rate..$^{[7,9,10]}$

Regardless of their etiology, the mainstay of management for symptomatic VCFs is targeted medical therapy, including analgesics, bed rest, external fixation, and re- habilitation. ${ }^{[11,12]}$ However, anti-inflammatory drugs and certain types of analgesics can be poorly tolerated by elderly patients, and bed rest may lead to further demineralization, predisposing the patient to future fractures. Moreover, because of the poor quality of osteoporotic bone, surgical fixation often fails. ${ }^{[13]}$ Further, because of the risks of open surgery in elderly patients suffering from VCF, surgical procedures have generally been limited to cases where there is concurrent spinal instability or neurologic deficits. ${ }^{[8,9]}$

Balloon kyphoplasty and vertebroplasty are two minimally invasive, percutaneous surgical approaches that have recently been developed for the management of symptomatic VCFs. ${ }^{[14,15]}$ Vertebroplasty involves percutaneous injection of viscous polymethylmethacrylate (PMMA) into the vertebral body and was first described by Galibert et al. in 1987. ${ }^{[16]}$ In balloon kyphoplasty, a tamp (balloon) is inserted into the vertebral body using either a transpe-

From the Department of Orthopaedic Surgery, Chang Gung Memorial Hospital at Linkou, Chang Gung University College of Medicine, Taoyuan, Taiwan

Received: May 22, 2012; Accepted: Sep. 24, 2012

Correspondence to: Dr. Lih-Huei Chen, Department of Orthopaedic Surgery, Chang Gung Memorial Hospital at Linkou. 5, Fusing St., Gueishan, Taoyuan 333, Taiwan (R.O.C.). Tel: 886-3-3281200; ext. 2163; Fax: 886-3-3278113; E-mail: lhchen2132@ adm.cgmh.org.tw

DOI: $10.4103 / 2319-4170.112544$ 
dicular or extrapedicular route, leading to compression of cancellous bone, creation of a cavity, and if possible, realignment of the endplate of the vertebral body, and PMMA is then injected. After removal of the bone tamp, the injected PMMA fixes and stabilizes the fracture. Although there have been numerous studies investigating the efficacy of vertebroplasty and kyphoplasty for the treatment of VCF, much of the literature is from retrospective studies or case series.

The purpose of this study was to perform a comprehensive review of the literature and conduct a meta-analysis to compare clinical outcomes of pain relief and function, radiographic outcomes of the restoration of anterior vertebral height (AVH) and kyphotic angles, and subsequent complications associated with these two techniques.

\section{Literature search}

A number of bibliographic databases were searched, including PubMed, Medline, ACP Journal Club, DARE, CCTR, CDSR, and the Cochrane Library. Searches were conducted using the terms "vertebroplasty" or "kyphoplasty" and the results were restricted to reports that were published from April 1998 to March 2011. Abstracts were reviewed, and studies containing information on pain relief or complications after vertebroplasty or kyphoplasty were saved for further review.

From this literature, data on preoperative visual analog scale (VAS), postoperative VAS, changes in VAS, and functional scores such as the Oswestry Disability Index and Short Form 36 were collected. Any complications related to either vertebroplasty or kyphoplasty were also identified. Demographic data were also collected, including the sample size, gender, mean age, diagnoses, number of levels treated, and length of follow-up. Moreover, because of the large number of case series available in the literature, only systematic reviews and controlled studies were included.

\section{Statistical analyses}

Pooled preoperative and postoperative VAS data were analyzed using paired $t$ tests to determine whether any significant differences existed for the combined population. Changes in VAS scores and functional scores were also compared using standard $t$ tests to determine whether there were significant differences in the degree of postoperative changes following vertebroplasty and kyphoplasty. Studies that reported associated complications were identified, and the overall complication rate was calculated by examining the occurrence of complications in relation to the total number of procedures and patients in each series. A Chi-square analysis was performed to identify any significant differences in the rate of cement leak, pulmonary embolism, neurological complication, or new fracture after vertebroplasty versus kyphoplasty. However, if the total number of procedures performed or number of patients treated was not reported in the case reports, these cases were not included in the risk analysis.

\section{Surgical technique}

Percutaneous vertebroplasty has been thoroughly described in previous studies. ${ }^{[17]}$ The general methodology used for kyphoplasty is described below. Percutaneous kyphoplasty is performed under local anesthesia with patients in the prone position. Preoperative prophylactic first-generation cephalosporin is administered to each patient, and fluoroscopy is used throughout the procedure. An incision is made on the pedicle level of the skin, and the correct incision site is identified using the anteroposterior (AP) view of the image intensifier. An inflatable balloon is then inserted unilaterally into the fractured vertebral body, and a needle pipe and pin are placed via the incision, with the tip placed lateral to the pedicle projection in the AP view and parallel to the superior endplate in the lateral view [Figure 1]. The needle pin is then removed, and the wire pin is introduced into two-thirds of the vertebral body. The needle pipe is subsequently removed, and a cannular and expander are inserted into the pedicle through the wire pin [Figure 2]. After removal of the wire pin and insertion of the drill, the balloon is slowly inflated [Figure 3]. The volume of the balloon is controlled in order to recover the damaged vertebral body until adequate kyphotic angle reduction is obtained or the inflation pressure reaches 220 psi. The amount of injected fluid can be used to predict the cement volume [Figure 4]. Thereafter, the balloon is deflated and withdrawn, and the resulting intravertebral cavity is filled with PMMA cement [Figure 5].

\section{Selection of studies}

A total of 791 citations related to either vertebroplasty or kyphoplasty were identified. All studies that used additional instrumentation, compared the results with conservative treatment, used non-PMMA augmentation, had VCFs related to metastatic compression fractures, or were not available in full-text format were excluded. Of the remaining 187 citations, case series, review articles, publications describing novel basic technologies, and technique reports were eliminated. The remaining 14 studies, including 7 systematic reviews ${ }^{[18-24]}$ and 7 controlled studies, ${ }^{[25-31]}$ were saved and reviewed. The selection process is described in Figure 6.

\section{Demographic data}

From the seven systematic review studies, the results of 336 subjects, including 45 patients from prospective studies and 291 patients from retrospective studies conducted between 1996 and 2007, were presented, with follow-up ranging from 1 
to 5 years [Table 1]. Of the seven controlled studies, four were prospective and three were retrospective, including 393 patients with a mean age of 76 years (range, 58-92) who underwent 194 kyphoplasties and 199 vertebroplasties [Table 2].

\section{Outcomes: Pain and functional improvement}

Within the seven systematic reviews, specific data

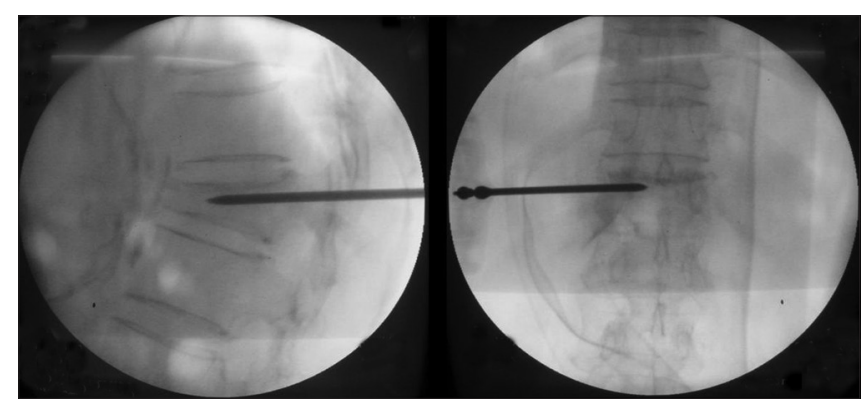

Figure 1: The procedure was performed with local anesthesia and the patient lying prone. A stab incision was made on the pedicle level of the skin. The correct incision site was identified with the anteroposterior (AP) view of the image intensifier. A needle pipe and pin were placed via a stab incision. The tip was lateral to the pedicle projection in the AP view and parallel to the superior endplate in the lateral view.

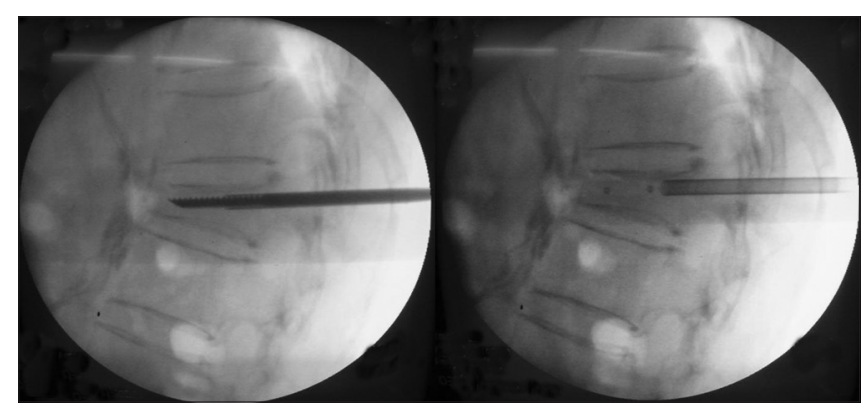

Figure 3: Remove the wire pin and insert the drill through the cannular. Slowly inflate the balloon with initial bulk pressure.

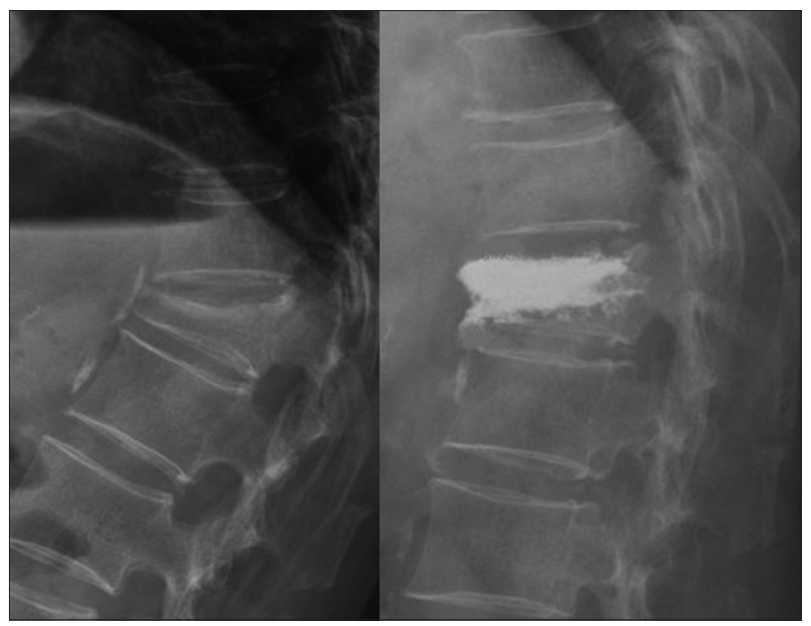

Figure 5: The balloon is deflated and withdrawn, and the resulting intravertebral cavity is filled with PMMA cement. for VAS scores after kyphoplasty and vertebroplasty were identified for 336 subjects. ${ }^{[18-24]}$ Mean improvements in

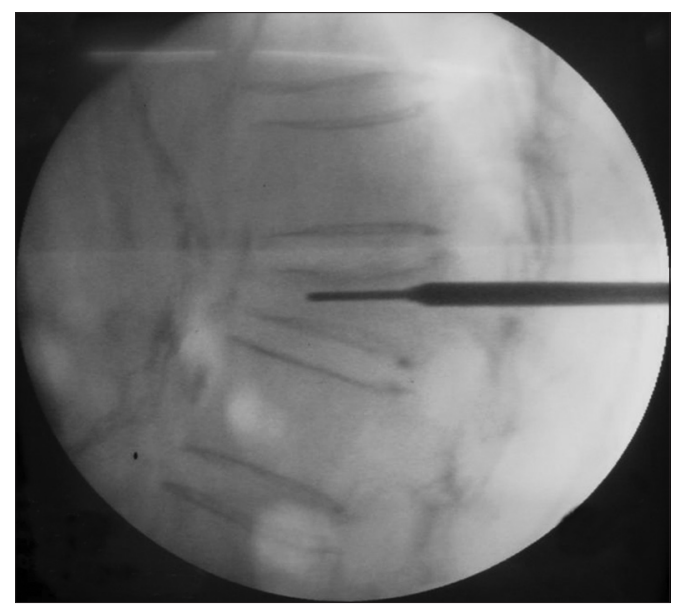

Figure 2: Remove the needle pin, introduce the wire pin into twothirds of the vertebral body, and remove the needle pipe. A cannular and expander are inserted into the pedicle through the wire pin.

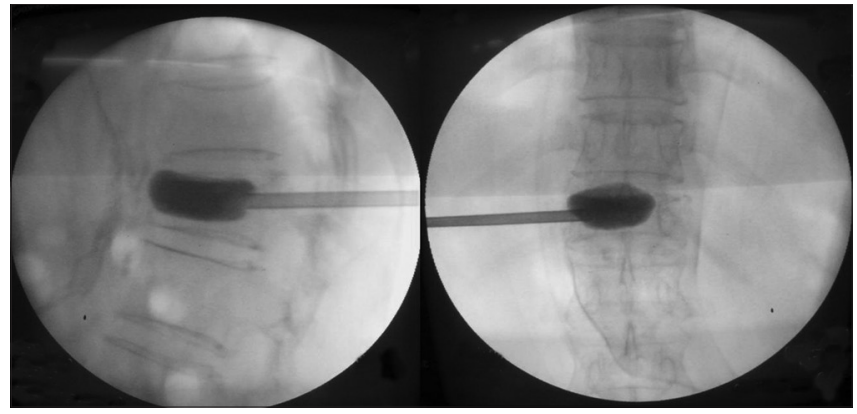

Figure 4: The operator controls the volume of the balloon to recover the damaged vertebral body with micro-pressure until adequate kyphotic angle reduction is obtained or the inflation pressure reaches 220 psi. The operator should record the amount of injected fluid to predict the cement volume.

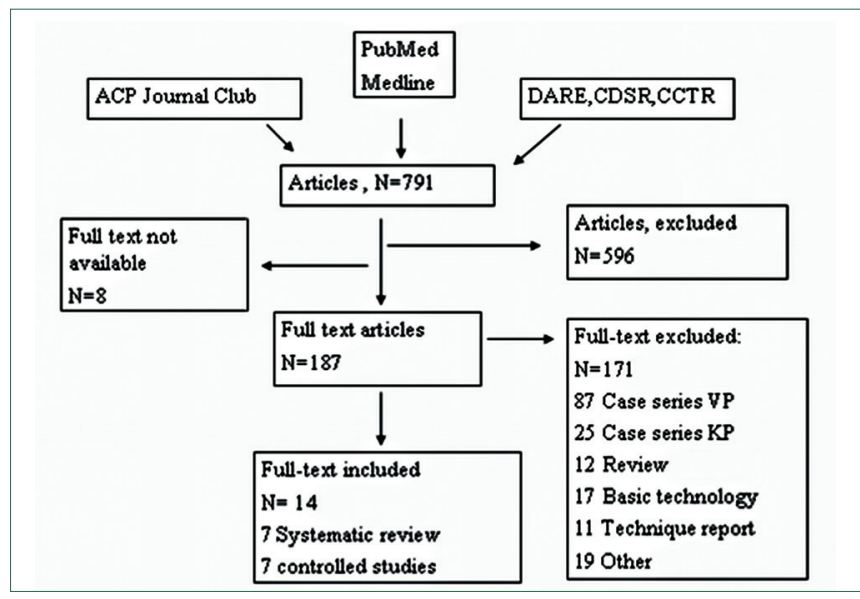

Figure 6: A total of 791 citations related to either vertebroplasty or kyphoplasty were identified. The remaining 14 studies, including 7 systematic reviews and 7 controlled studies, were saved and reviewed. The selection process is described. 
VAS scores ranged from 3.6 to 5.6 in the kyphoplasty group and from 2.6 to 5.6 in the vertebroplasty group. There was no statistically significant difference between the two groups in terms of pain improvement $(p>0.01)$ [Figure 7]. One-day [Figure 8] and 1-year [Figure 9] pain improvement in the seven controlled studies were also not statistically significant. Functional outcomes in the three retrospective controlled studies were not statistically significant at either the 1-day [Figure 10] or 1-year [Figure 11] follow-up.

\section{Radiographic outcomes}

AVH restoration in the four prospective controlled studies ranged from $6.5 \%$ to $33.0 \%$ in the kyphoplasty group and from $0 \%$ to $13.7 \%$ in the vertebroplasty group. There was a statistically greater improvement in AVH restoration after kyphoplasty than in AVH restoration after vertebroplasty $(p<0.05)$ in one study [Figure 12].

Kyphotic angle restoration in the four prospective

Table 1: The seven systematic reviews

\begin{tabular}{|c|c|c|c|}
\hline Author/year/journal & Selected studies & Time & Follow-up \\
\hline $\begin{array}{l}\text { Hadjipavlou, et al. } \\
\text { 2005, JBJS-A }{ }^{[18]}\end{array}$ & $\begin{array}{l}17 \text { Prospective } \\
\text { non randomized } 7 \\
\text { retrospective }\end{array}$ & $1997-2005$ & Not \\
\hline $\begin{array}{l}\text { Taylor et al. 2006, } \\
\text { Spine }^{[19]}\end{array}$ & 17 KP 59 VP & $2000-2005$ & $0-5$ years \\
\hline $\begin{array}{l}\text { Hulme et al. 2006, } \\
\text { Spine }{ }^{[20]}\end{array}$ & $\begin{array}{l}22 \mathrm{KP}-1288 \text { patients } \\
103 \mathrm{VP}-7587 \text { patients }\end{array}$ & 1999-2005 & Not \\
\hline $\begin{array}{l}\text { Eck et al. 2008, } \\
\text { Spine } \mathrm{J}^{[21]}\end{array}$ & $\begin{array}{l}7 \text { KP-263 } 14 \\
\text { VP-1046 }\end{array}$ & 1996-2006 & $1-5$ years \\
\hline $\begin{array}{l}\text { Gill et al. 2007, Pain } \\
\text { Physician }^{[22]}\end{array}$ & $\begin{array}{l}15 \text { prospective } 6 \\
\text { retrospective }\end{array}$ & $2000-2007$ & $\begin{array}{l}\text { Average } \\
1.5 \text { years }\end{array}$ \\
\hline $\begin{array}{l}\text { Bouza et al. 2006, } \\
\text { Eur Spine } \mathbf{J}^{[23]}\end{array}$ & $\begin{array}{l}5 \text { non-randomized } \\
\text { case control } 21 \text { case } \\
\text { series }\end{array}$ & $2000-2005$ & $\begin{array}{l}\text { Average } \\
2 \text { years }\end{array}$ \\
\hline $\begin{array}{l}\text { Taylor et al. 2007, } \\
\text { Eur Spine } \mathbf{J}^{[24]}\end{array}$ & $\begin{array}{l}8 \text { non-randomized } \\
\text { case control } 35 \text { case } \\
\text { series }\end{array}$ & 2001-2005 & $\begin{array}{l}3 \text { months } \\
\text { to } 4 \text { years }\end{array}$ \\
\hline
\end{tabular}

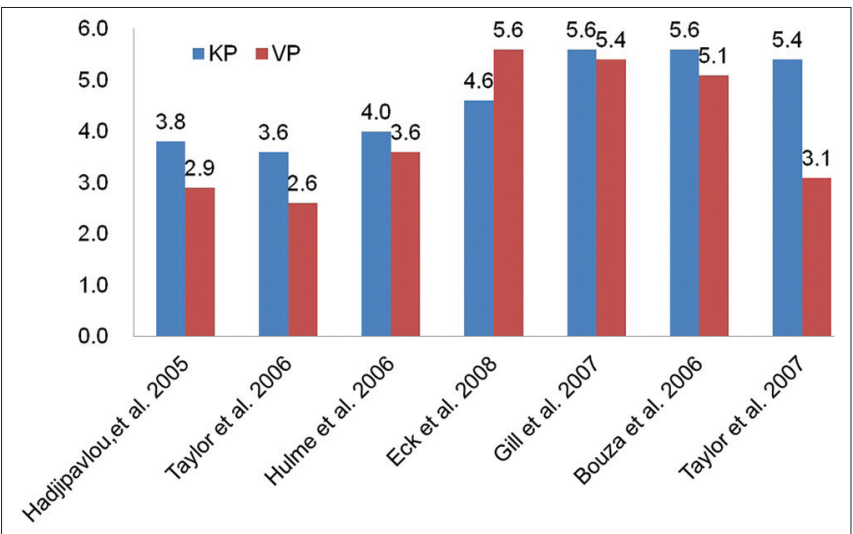

Figure 7: Comparison of pain reduction between kyphoplasty group and vertebroplasty group in the seven systematic reviews. controlled studies ranged from 6 to 7.9 in the kyphoplasty group and from 0 to 4.6 in the vertebroplasty group. There was a statistically greater improvement in kyphotic angle correction after kyphoplasty than in kyphotic angle correction after vertebroplasty $(p<0.001)$ in two studies [Figure 13].

\section{Complications}

The literature search identified five systematic reviews and seven controlled studies that described the occurrence of cement leakage after vertebroplasty or kyphoplasty. Moreover, five systematic reviews described the occurrence of new fractures. Cement leakage out of the vertebral body occurred in $0-15 \%$ of patients after kyphoplasty and $0.3-41 \%$ of patients after vertebroplasty [Figure 14]. Pulmonary embolisms caused by cement leakage occurred in $0-1.2 \%$ of patients following kyphoplasty and $0.17-11 \%$ of patients after vertebroplasty [Figure 15], and neurological complications resulting from cement leakage occurred in $0-2.9 \%$ of patients after kyphoplasty and $0.03-23 \%$ of

Table 2: The seven controlled studies

\begin{tabular}{|c|c|c|c|}
\hline Author/year/Journal & $\begin{array}{l}\text { Inclusion criteria } \\
\text { for patients }\end{array}$ & $\begin{array}{l}\text { Numbers } \\
\text { of patients }\end{array}$ & $\begin{array}{c}\text { Mean } \\
\text { age }(\mathrm{SD})\end{array}$ \\
\hline $\begin{array}{l}\text { Grohs et al. } 2005 \text {, } \\
\text { JSDT }^{[25]}\end{array}$ & $\begin{array}{l}\text { Failed to } \\
\text { conservative } \\
\text { treatment }\end{array}$ & $\begin{array}{l}\text { KP } 28 \\
\text { VP } 23\end{array}$ & $\begin{array}{l}\text { KP } 70 \mathrm{yr} \\
\text { VP } 70 \mathrm{yr}\end{array}$ \\
\hline $\begin{array}{l}\text { Pflugmacher et al. } \\
\text { 2005, Rofo }\end{array}$ & $\begin{array}{l}\text { Kyphosis }>10,2 \\
\text { weeks to } 3 \text { months }\end{array}$ & $\begin{array}{l}\text { KP } 22 \\
\text { VP } 20\end{array}$ & $\begin{array}{l}\text { KP } 67 \mathrm{yr} \\
\text { VP } 65 \mathrm{yr}\end{array}$ \\
\hline $\begin{array}{l}\text { De Negri et al. 2007, } \\
\text { Clin J Pain }{ }^{[27]}\end{array}$ & $<6$ months & $\begin{array}{l}\text { KP } 11 \\
\text { VP } 10\end{array}$ & NA \\
\hline $\begin{array}{l}\text { Frankel et al. 2007, } \\
\text { Spine }^{[28]}\end{array}$ & $\begin{array}{l}\text { Failed to } \\
\text { conservative } \\
\text { treatment }\end{array}$ & $\begin{array}{l}\text { KP } 17 \\
\text { VP } 19\end{array}$ & $\begin{array}{l}\text { KP } 70 \mathrm{yr} \\
\text { VP } 72 \mathrm{yr}\end{array}$ \\
\hline $\begin{array}{l}\text { Zhou JL et al., 2008, } \\
\text { Chin J Traumatol }{ }^{[29]}\end{array}$ & $\begin{array}{l}\text { AVH decrease } \\
50-75 \%\end{array}$ & $\begin{array}{l}\text { KP } 41 \\
\text { VP } 57\end{array}$ & $\begin{array}{l}\text { KP } 62 \text { yr } \\
\text { VP } 64 \text { yr }\end{array}$ \\
\hline $\begin{array}{l}\text { Schofer MD et al. } \\
\text { 2009, Arch Orthop } \\
\text { Trauma Surg }{ }^{[30]}\end{array}$ & Fresh fracture & $\begin{array}{l}\text { KP } 30 \\
\text { VP } 30\end{array}$ & $\begin{array}{l}\text { KP } 68 \mathrm{yr} \\
\text { VP } 66 \mathrm{yr}\end{array}$ \\
\hline $\begin{array}{l}\text { Li X et al. 2011, } \\
\text { JSDT }^{[31]}\end{array}$ & $<1$ month & $\begin{array}{l}\text { KP } 45 \\
\text { VP } 40\end{array}$ & $\begin{array}{l}\text { KP } 68 \text { yr } \\
\text { VP } 67 \mathrm{yr}\end{array}$ \\
\hline
\end{tabular}

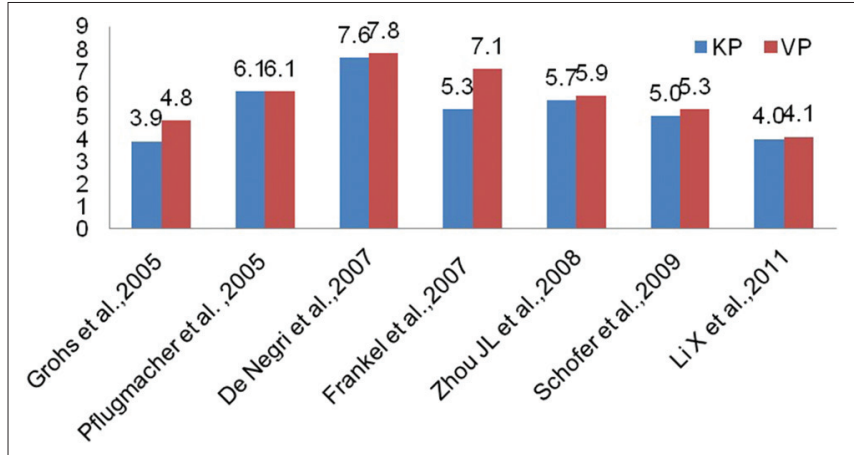

Figure 8: Comparison of 1-day pain between kyphoplasty group and vertebroplasty group in the seven controlled studies. 


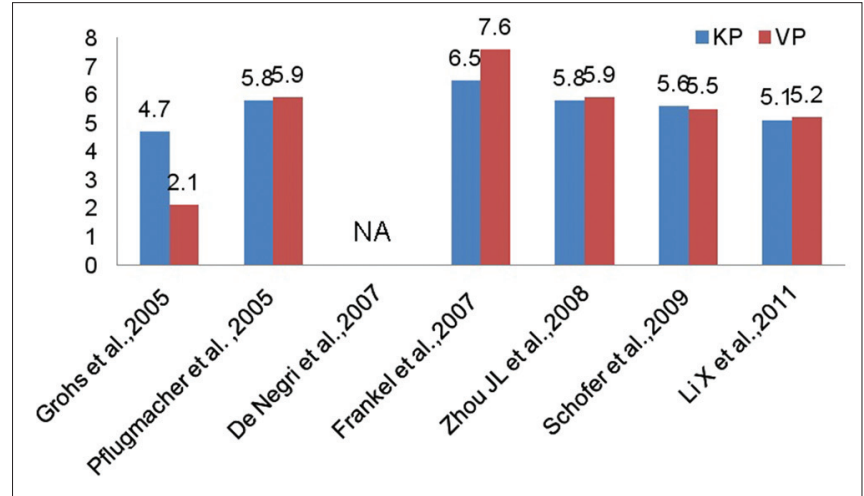

Figure 9: Comparison of 1-year pain between kyphoplasty group and vertebroplasty group in the seven controlled studies.

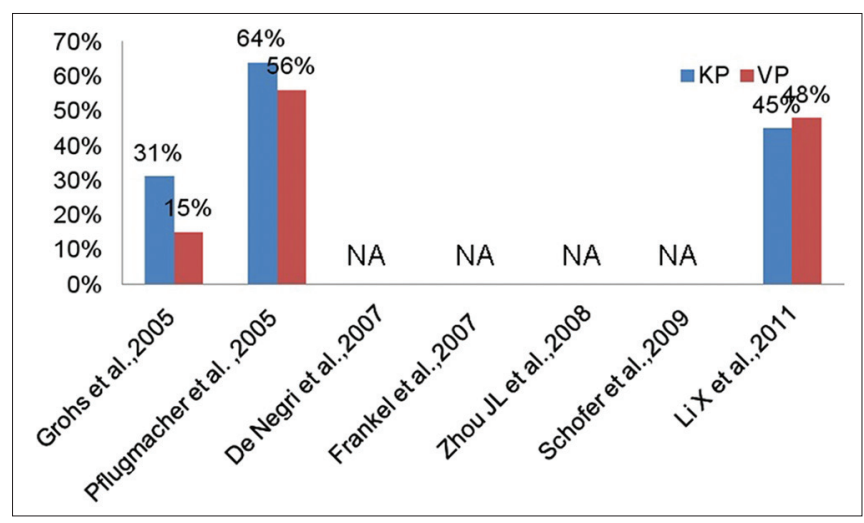

Figure 11: Comparison of 1-year function between kyphoplasty group and vertebroplasty group in the seven controlled studies.

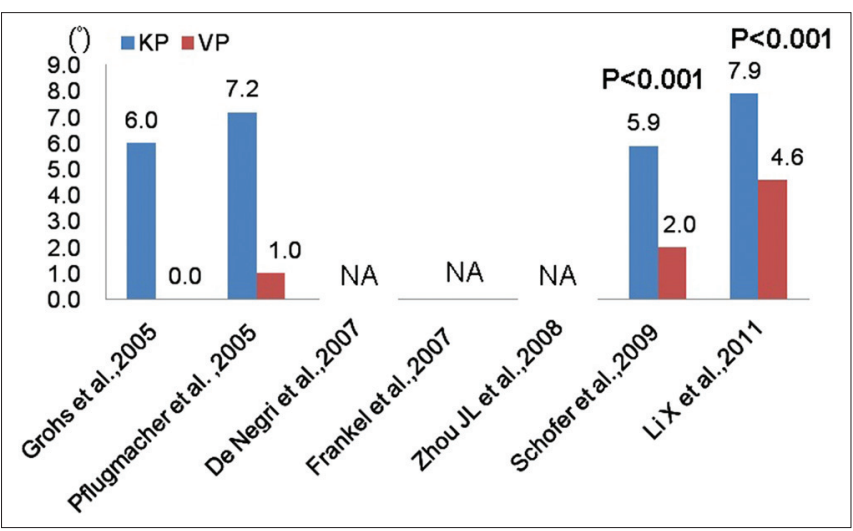

Figure 13: Comparison of radiographic outcomes including kyphotic angle restoration between kyphoplasty group and vertebroplasty group in the seven controlled studies.

patients after vertebroplasty [Figure 16]. The prevalence of new compression fractures was 9-37\% after kyphoplasty and $10-52 \%$ after vertebroplasty [Figure 17].

\section{Discussion}

Vertebroplasty and kyphoplasty are well-established

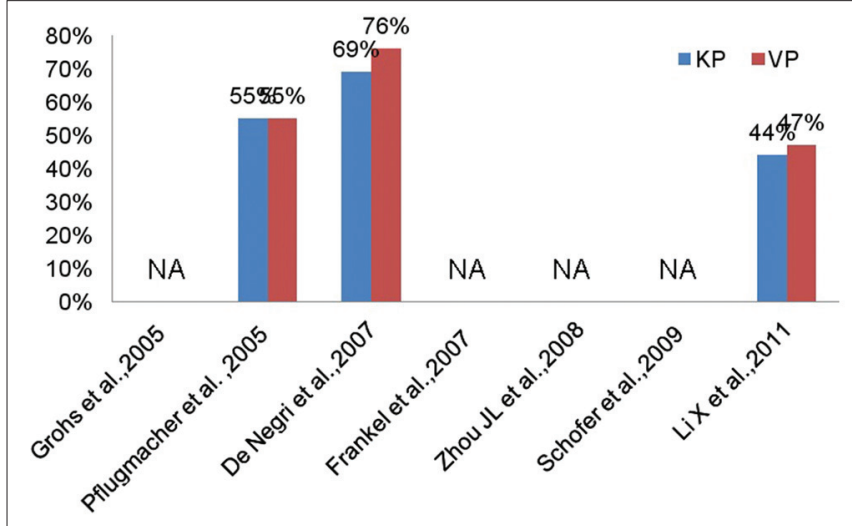

Figure 10: Comparison of 1-day function between kyphoplasty group and vertebroplasty group in the seven controlled studies.

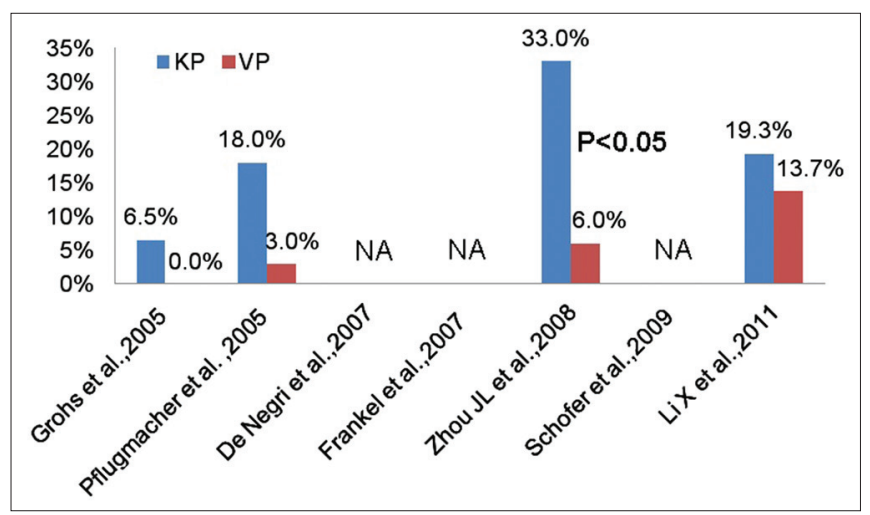

Figure 12: Comparison of radiographic outcomes including anterior vertebral height restoration between kyphoplasty group and vertebroplasty group in the seven controlled studies.

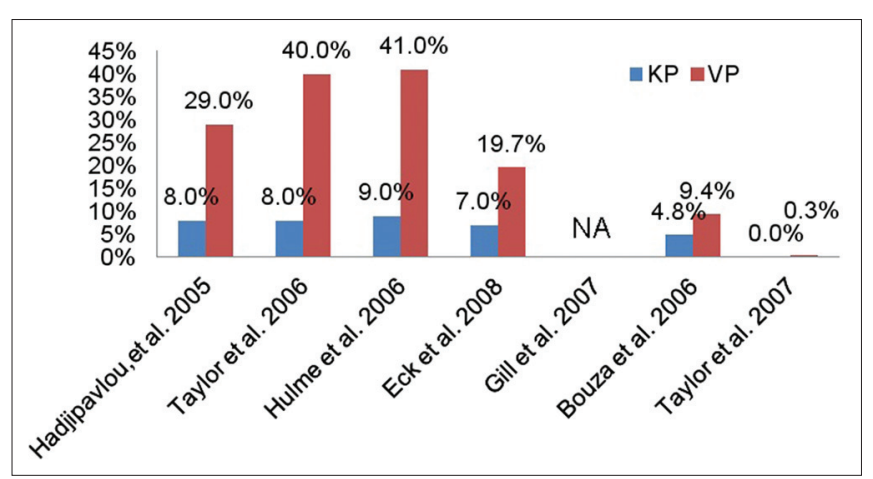

Figure 14: Comparison of cement leakage between kyphoplasty group and vertebroplasty group in the seven systematic reviews.

techniques that have been reported to provide significant relief to patients with painful VCFs related to osteoporosis, multiple myeloma, hemangioma, and metastases. ${ }^{[16]}$ Unfortunately, much of the current literature investigating vertebroplasty and kyphoplasty consists of retrospective cases series and case reports. Moreover, few studies have directly compared vertebroplasty and kyphoplasty. The purpose of this study 


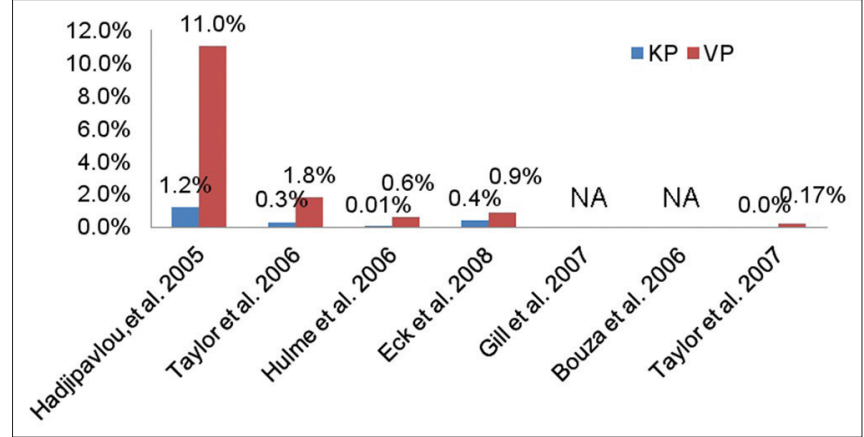

Figure 15: Comparison of pulmonary embolism between kyphoplasty group and vertebroplasty group in the seven systematic reviews.

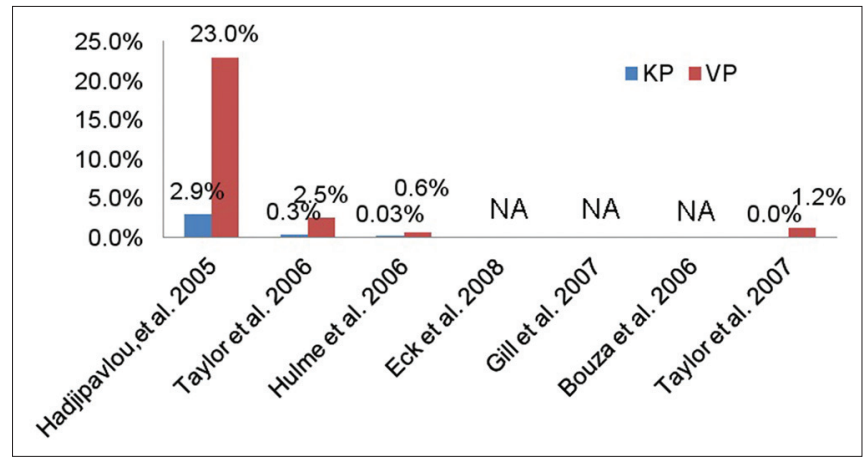

Figure 16: Comparison of neurological complication between kyphoplasty group and vertebroplasty group in the seven systematic reviews.

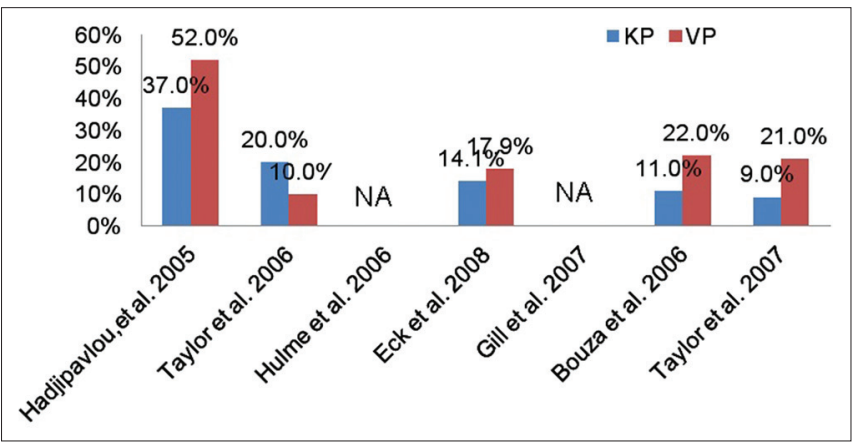

Figure 17: Comparison of new fracture between kyphoplasty group and vertebroplasty group in the seven systematic reviews.

was to perform a comprehensive review of the literature to determine the effectiveness of vertebroplasty and kyphoplasty in treating symptomatic VCFs and to assess the risk of complications associated with these two common techniques.

\section{Clinical outcomes}

The combined data revealed that both vertebroplasty and kyphoplasty were effective in reducing pain and improving functional outcomes. Statistically significant improvements were achieved after both techniques, and mean improvements in VAS scores for both vertebroplasty and kyphoplasty exceeded 33\% change, which has been reported to be a reasonable standard for meaningful change. ${ }^{[32]}$

\section{Complications}

Vertebroplasty compared with kyphoplasty was found to be associated with a significantly greater risk of cement leak, which resulted in a relatively higher risk of pulmonary embolism and neurological complications such as myelopathy or radiculopathy. It has been suggested that this difference is reflective of the creation of the cavity and the use of more viscous cement in balloon kyphoplasty. ${ }^{[33-35]}$

With vertebroplasty, the cement must be able to fill the gaps between fracture fragments and thus must be less viscous, allowing it to more easily leak through defects in the cortex. Additionally, it is believed that the impaction of the trabecular bone against the surrounding cortical bone reduces the risk of cement penetrating the cortex. Another factor related to the leakage of cement in both vertebroplasty and kyphoplasty is the fracture pattern. Disruption of the endplates and anterior or posterior wall fractures can increase the risk of cement leaks. In the studies reviewed here, the majority of leaks were asymptomatic, incidental findings; however, these leaks can lead to both minor and major complications. Patients may develop transient radicular pain after a cement leak into the foramen or spinal canal. Furthermore, larger cement volumes have the potential to cause spinal cord compression and paralysis. Many patients with these cement leaks need to return to the operating room for emergent decompression and stabilization. ${ }^{[36-41]}$

\section{New fractures}

Pooling the results of the five systematic reviews reporting incident vertebral fractures revealed a significant reduction in the incidence of new fractures with balloon kyphoplasty compared with vertebroplasty. This may have resulted from the decreased occurrence of cement leakage into the vertebral discs and the better sagittal alignment achieved by kyphoplasty. ${ }^{[42,43]}$ In studies of vertebroplasties, intradiscal cement leakage had an odds ratio of $4.633 .{ }^{[42]}$ Other variables, including age, gender, bone mineral density, number of procedures, number of vertebrae treated, amount of cement injected, and cement leakage into the soft tissues or veins, did not increase the risk of new VCFs. Prior studies have reported that patients who have had a VCF have a fourfold higher risk of experiencing an additional VCF than patients who have not had a VCF. ${ }^{[44}$ This supports the argument that there is an increased risk of developing additional VCFs after vertebroplasty than in patients with osteoporosis. This finding is in contrast to two recently published studies suggesting that a greater level of complications occurs after balloon kyphoplasty than after vertebroplasty ${ }^{[45]}$ and that there is an increased incidence of VCFs following balloon kyphoplasty relative to patients with no history of fractures. ${ }^{[46]}$ However, the findings of these two studies must be interpreted within the context of all available 
evidence, and they have both received considerable criticism on the basis of their poor methodology. ${ }^{[47,48]}$

\section{Cost-effectiveness}

Ström et al. in 2010 developed a Markov cost-effectiveness model to estimate the cost-effectiveness of balloon kyphoplasty compared with non-surgical management in a UK setting. ${ }^{[49]}$ The procedure was associated with quality-adjusted life-years (QALY)-gains of 0.17 and cost/ QALY-gains at $\leq 8800$. The results were sensitive to assumptions about avoided length of hospital stay and persistence of kyphoplasty-related quality of life benefits. In 2012, a Markov simulation model was developed to evaluate treatment with balloon kyphoplasty, non-surgical management, and percutaneous vertebroplasty in patients with symptomatic osteoporotic VCFs. ${ }^{[50]}$ The incremental cost-effectiveness ratio of kyphoplasty was estimated at Great Britain Pound Sterling (GBP) 2706 per QALY and GBP 15,982 per QALY compared to non-surgical management and vertebroplasty, respectively. In conclusion, the results indicate that kyphoplasty provides a cost-effective alternative for treating patients with hospitalized VCFs in a UK-setting.

\section{Strengths and limitations}

The principal strength of this review is its comprehensiveness. We undertook exhaustive searches of the literature and sought all published and unpublished evidence. Inevitably, any review can be subject to publication bias, i.e. studies with "positive" results are more likely to be reported and published, while side effects and adverse events are more likely to be underreported.

The principal limitation in the interpretation of the findings of this review was the absence of prospective randomized controlled trial (or "level I") evidence. However, it is important to point out that although case series studies are relatively low in the hierarchy of evidence, well-conducted and adequately reported studies can provide useful data on the "real world" effectiveness and safety of the procedure. Furthermore, as discussed above, this review has identified a growing number of direct, albeit non-randomized, comparative studies. It is recognized that because of non-random allocation of patients to intervention and control, studies are prone to substantial selection bias and confounding.

\section{Conclusions}

Both percutaneous vertebroplasty and balloon kyphoplasty have been shown to be effective in controlling pain and improving function. Kyphoplasty not only has the advantage of improving or restoring vertebral height and kyphotic deformities, but can also decrease cement leakage and reduce the occurrence of new fracture. Although there was a good ratio of benefit to harm for both procedures, balloon kyphoplasty appears to have a less short-term adverse event in cement leakage and new fractures. Effectiveness and safety between the two procedures require confirmation by more prospective, randomized, controlled trials.

\section{REFERENCES}

1. Old JL, Calvert M. Vertebral compression fractures in the elderly. Am Fam Physician 2004;69:111-6.

2. Hall SE, Criddle RA, Comito TL, Prince RL. A case-control study of quality of life and functional impairment in women with long-standing vertebral osteopo-rotic fractures. Osteoporos Int 1999;9:508-15.

3. Report on Osteoporosis in the European Commission. European Commission, DG employment, industrial relations and Social Affairs, 1998. Available from: http://www.osteofound.org/ publications/pdf/eu_report_98.pdf. [Last accessed on 2004 Nov 01].

4. Melton LJ $3^{\text {rd }}$, Kan SH, Frye MA, Wahner HW, O'Fallon WM, Riggs BL. Epidemiology of vertebral fractures in women. Am J Epidemiol 1989;129:1000-11.

5. Silverman SL. The clinical consequences of vertebral compression fracture. Bone 1992;13 Suppl 2:S27-31.

6. Pluijm SM, Tromp AM, Smit JH, Deeg DJ, Lips P. Consequences of vertebral deformities in older men and women. J Bone Miner Res 2000;15:1564-72.

7. Kado DM, Browner WS, Palermo L, Nevitt MC, Genant HK, Cummings SR. Vertebral body fractures and mortality in older women: A prospective study. Arch Intern Med 1999;159:1215-20.

8. Schlaich C, Minne HW, Bruckner T, Wagner G, Gebest HJ, Grunze M, et al. Reduced pulmonary function in patients with spinal osteoporotic fractures. Osteoporos Int 1998;8:261-7.

9. Linville DA $2^{\text {nd }}$. Vertebroplasty and kyphoplasty. South Med J 2002;95:583-7.

10. Cotten A, Boutry N, Cortet B, Assaker R, Demondion X, Leblond D, et al. Percutaneous vertebroplasty: State of the art. Radiographics 1998; 18:311-20.

11. Rapado A. General management of vertebral fractures. Bone 1996;18(Suppl 3):S191-6.

12. Reginster J, Minne HW, Sorensen OH, Hooper M, Roux C, Brandi ML, et al. Randomized controlled trial of risedronate on vertebral fractures in women with established postmeno-pausal osteoporosis. Osteoporos Int 2000;11:83-91.

13. Dickman C, Fessler RG, MacMillan M, Haid RW. Transpedicular screw-rod fixation of the lumbar spine: Operative technique and outcome in 104 cases. J Neurosurg 1992;77:860-70.

14. Phillips FM, Wetzel FT, Lieberman I, Campbell-Hupp M. An in vivo comparison of the potential for extravertebral cement leak after vertebroplasty and kyphoplasty. Spine 2002;27:2173-8.

15. Liebermann I, Reinhardt MK. Vertebroplasty and kyphoplasty for osteolytic vertebral collapse. Clin Orthop 2003;415(Suppl):176-86.

16. Galibert P, Deramond H, Rosat P, Le Gars D. Preliminary note on the treatment of vertebral angioma by percutaneous acrylic vertebroplasty. Neurochirurgie 1987;33:166-8. 
17. Chen LH, Niu CC, Yu SW, Fu TS, Lai PL, Chen WJ. Minimally invasive treatment of osteoporotic vertebral compression fracture. Chang Gung Med J 2004;27:261-7.

18. Hadjipavlou AG, Tzermiadianos MN, Katonis PG, Szpalski M. Percutaneous vertebroplasty and ballon kyphoplasty for the treatment of osteoporotic vertebral compression fractures and osteolytic tumours. J Bone Joint Surg Am 2005;87:1595-604.

19. Taylor RS, Taylor RJ, Fritzell P. Balloon kypho-plasty and vertebroplasty for vertebral compression fractures: A comparative systematic review of efficacy and safety. Spine 2006;31:2747-55.

20. Hulme PA, Krebs J, Ferguson SJ, Berlemann U. Vertebroplasty and kyphoplasty: A systematic review of 69 clinical studies. Spine 2006;31:1983-2001

21. Eck JC, Nachtigall D, Humphreys SC, Hodges SD. Comprasion of vertebroplasty and balloon kyphoplasty for treatment of vertebral compression fractures: A meta-analysis of the literature. Spine J 2008;8:488-97.

22. Gill JB, Kuper M, Chin PC, Zhang Y, Schutt R Jr. Comparing pain reduction following kyphoplasty and vertebroplasty for osteoporotic vertebral compression fractures. Pain Physician 2007;10:583-90.

23. Bouza C, Lopez T, Magro A, Navalpotro L, Amate JM. Efficacy and safety of balloon kyphoplasty in the treatment of vertebral compression fractures: A systematic review. Eur Spine J 2006;15:1050-67.

24. Taylor RS, Fritzell P, Taylor RJ. Balloon kypho-plasty in the management of vertebral compression fractures: An updated systematic review and meta-analysis. Eur Spine J 2007;16:1085-100.

25. Grohs JG, Matzner M, Trieb K, Krepler P. Minimal invasive stabilization of osteoporotic vertebral fractures - A prospective nonrandomized comparison of vertebroplasty and balloon kyphoplasty. J Spinal Disord Tech 2005;18:238-42.

26. Pflugmacher R, Kandziora F, Schröder R, Schleicher P, Scholz M, Schnake K, et al. Vertebroplasty and kyphoplasty in osteoporotic fractures of vertebral bodies - a prospective 1-year follow-up analysis. Rofo 2005;177:1670-6.

27. De Negri P, Tirri T, Paternoster G, Modano P. Treatment of painful osteoporotic or traumatic vertebral compression fractures by percutaneous vertebral augmentation procedures. Clin J Pain 2007;23:425-30.

28. Frankel BM, Monroe T, Wang C. Percutaneous vertebral augmentation: An elevation in adjacent-level fracture risk in kyphoplasty as compared with vertebroplasty. Spine 2007;7:575-82.

29. Zhou JL, Liu SQ, Ming JH, Peng H, Qiu B. Comparison of therapeutic effect between percutaneous vertebroplasty and kyphoplasty on vertebral compression fracture. Chin J Traumatol 2008; 11:42-4.

30. Schofer MD, Efe T, Timmesfeld N, Kortmann HR, Quante M. Comparison of kyphoplasty and vertebroplasty in the treatment of fresh vertebral compression fractures. Arch Orthop Trauma Surg 2009;129:1391-9.

31. Li X, Yang H, Tang T, Qian Z, Chen L, Zhang Z. Comparison of kyphoplasty and vertebroplasty for treatment of painful osteoporotic vertebral compression fractures: Twelve-month follow-up in a prospective nonrandomized comparative study. J Spinal Disord Tech 2012;25:142-9.

32. Hanley MA, Jensen MP, Ehde DM, Robinson LR, Cardenas DD, Turner JA, et al. Clinically significant change in pain intensity ratings in persons with spinal cord injury or amputation. Clin J Pain 2006;22:25-31.
33. Heini PF, Orler R. Kyphoplasty for treatment of osteoporotic vertebral fractures. Eur Spine J 2004;13:184-92.

34. Cortet B, Cotten A, Boutry N, Flipo RM, Duquesnoy B, Chastanet P, et al. Percutaneous vertebroplasty in the treatment of osteoporotic vertebral compression fractures: An open prospective study. J Rheumatol 1999;26:2222-8.

35. Heini PF, Dain Allred C. The use of a side-opening injection cannula in vertebroplasty: A technical note. Spine 2002;27:105-9.

36. Hochegger M, Radl R, Leithner A, Windhager R. Spinal canal stenosis after vertebroplasty. Clin Radiol 2005;60:397-400.

37. Lopez NM, Lopes VK. Paraplegia complicating percutaneous vertebroplasty for osteoporotic vertebral fracture. Arq Neuropsiquiatr 2004;62:879-81.

38. Seo JS, Kim YJ, Choi BW, Choe KO. MDCT of pulmonary embolism after percutaneous vertebroplasty. Am J Radiol 2005;184:1364-5.

39. Teng MM, Cheng H, Ho DM, Chang CY. Intraspinal leakage of bone cement after vertebroplasty: A report of 3 cases. AJNR Am J Neuroradiol 2006;27:224-9.

40. Tsai TT, Chen WJ, Lai PL, Chen LH, Niu CC, Fu TS, et al. Polymethylmethacrylate cement dislodgement following percutaneous vertebroplasty: A case report. Spine 2003;28:E457-60.

41. Walker DH, Mummaneni P, Rodts GE Jr. Infected vertebroplasty Report of two cases and review of the literature. Neurosurg Focus 2004; 17:E6

42. Chen WJ, Kao YH, Yang SC, Yu SW, Tu YK, Chung KC. Impact of cement leakage into disks on the development of adjacent vertebral compression fractures. J Spinal Disord Tech 2010;23:35-9.

43. Komemushi A, Tanigawa N, Kariya S, Kojima H, Shomura Y, Komemushi S, et al. Percutaneous vertebroplasty for osteoporotic compression fracture: Multivariate study of predictors of new vertebral bode fracture. Cardiovasc Intervent Radiol 2006;239:195-200.

44. Klotzbuecher CM, Ross PD, Landsman PB, Abbott TA $3^{\text {rd }}$, Berger M. Patients with prior fractures have an increased risk of future fractures: A summary of the literature and statistical analysis. J Bone Miner Res 2000;15:721-39.

45. Nussbaum DA, Gailloud P, Murphy K. A review of complications associated with vertebroplasty and kyphoplasty as reported to the Food and Drug Administration medical device related website. J Vasc Interv Radiol 2004; 15:1185-92.

46. Fribourg D, Yang C, Sra P, Delamarter R, Bae H. Incidence of subsequent vertebral fractures after kyphoplasty. Spine 2004;29:2270-6.

47. Lieberman IH, Phillips FM, Togawa D, Modic M, Masaryk T, Obuchowski $\mathrm{N}$, et al. Vertebral augmentation and the limits of interpreting complications reported in the Food and Drug Administration manufacturer and user facility device experience database. J Vasc Interv Radiol 2004;15:1193-6.

48. Harrop JS, Prpa B, Reinhart MK, Lieberman I. Primary and secondary osteoporosis incidence of subsequent vertebral compression fractures after kyphoplasty. Spine 2004;29:2120-5.

49. Ström O, Leonard C, Marsh D, Cooper C. Cost-effectiveness of balloon kyphoplasty in patients with symptomatic vertebral compression fractures in a UK setting. Osteoporos Int 2010;21:1599- 608.

50. Svedbom A,Alvares L, Cooper C, Marsh D, Ström O. Balloon kyphoplasty compared to vertebroplasty and nonsurgical management in patients hospitalized with acute osteoporotic vertebral compression fracture: A UK cost-effectiveness analysis. Osteoporos Int 2013;24:355-67. 